\title{
ANALISIS PENGELOLAAN LABORATORIUM IPA DALAM MENINGKATKAN MUTU PEMBELAJARAN IPA DI SMP NEGERI 1 BANJAR
}

\author{
Priska Kartikasari', Nur IImiyati ${ }^{2}$, Adi Maladona ${ }^{3}$ \\ 1,2,3 Program Studi Pendidikan Biologi Universitas Galuh, Jl. R. E. Martadinata No.150, Ciamis, Indonesia \\ E-mail : priska.kartikasari921@gmail.com
}

\begin{abstract}
Laboratory management is an attempt to manage all laboratory device which is expected to improve the quality of learning. A laboratory can be managed properly determined from several factors that are interrelated with each other. Based on observations, Junior Highschoo 1 Banjar has a separate science laboratory, namely the biology laboratory and the physics laboratory. This study aims to determine the management of the science laboratory in improving the quality of science learning at Junior Highschoo 1 Banjar. The method used in this research is descriptive qualitative with a naturalistic approach. The target population of this research is the social situation of Junior Highschoo 1 Banjar related to the management of the science laboratory and the activities in it. The data was collected by triangulation in the form of observation, interviews, and documentation studies. From the research results, in general, the management of the science laboratory includes: 1) Planning, 2) Organizing, 3) Implementation, 4) supervision, has been carried out well. However, it still does not meet all the criteria included in the laboratory management device.
\end{abstract}

Keywords: Banjar, Management, Laboratory, Science.

\begin{abstract}
ABSTRAK
Pengelolaan laboratorium merupakan suatu usaha untuk mengelola semua perangkat laboratorium yang diharapkan dapat meningkatkan mutu pembelajaran. Suatu laboratorium dapat dikelola dengan baik ditentukan dari beberapa faktor yang saling berkaitan satu sama lain. Berdasarkan hasil observasi SMP Negeri 1 Banjar memiliki laboratorium IPA yang terpisah yaitu laboratorium biologi dan laboratorium fisika. Penelitian ini bertujuan untuk mengetahui pengelolaan laboratorium IPA dalam meningkatkan mutu pembelajaran IPA di SMP Negeri 1 Banjar. Metode yang digunakan dalam penelitian ini adalah deskriptif kualitatif dengan pendekatan naturalistik. Populasi target penelitian ini adalah situasi sosial SMP Negeri 1 Banjar yang berkaitan dengan pengelolaan laboratorium IPA serta aktifitas yang ada didalamnya. Pengumpulan data dilakukan dengan triangulasi yaitu berupa observasi, wawancara, studi dokumentasi. Dari hasil penelitian secara umum pengelolaan laboratorium IPA meliputi : 1) Perencanaan, 2) Pengorganisasian, 3) Pelaksanaan, 4) pengawasan, sudah terlaksana dengan baik. Namun, masih belum memenuhi semua kriteria yang tercakup dalam perangkat pengelolaan laboratorium.
\end{abstract}

Kata kunci: Banjar , Laboratorium, IPA, Pengelolaan,

Cara sitasi: Kartikasari, P., IImiati, N., \& Maladona, A. (2021). Analisis Pengelolaan Laboratorium Ipa Dalam Meningkatkan Mutu Pembelajaran Ipa Di Smp Negeri 1 Banjar. J-KIP (Jurnal Keguruan dan IImu Pendidikan), 2 (3), 251-258. 


\section{PENDAHULUAN}

Pembelajaran IPA tidak dapat dipisahkan dengan kegiatan praktikum. Praktikum merupakan suatu rangkaian kegiatan yang memungkinkan seseorang (peserta didik) menerapkan keterampilan atau memprakatikan sesuatu (Syafri, et al., 2013). Tentunya dalam mendukung kegiatan praktikum tidak bisa dipisahkan dengan laboratorium. Secara garis besar fungsi laboratorium dalam proses pendidikan yaitu: sebagai tempat untuk berlatih mengembangkan ketrampilan intelektual melalui kegiatan pengamatan, pencatatan gejala-gejala alam; mengembangkan keterampilan motorik peserta didik, peserta didik akan bertambah keterampilannya dalam mempergunakan alat-alat media yang tersedia untuk mencari dan menemukan kebenaran; memberikan keberanian untuk mencari hakikat kebenaran ilmiah.

Mengingat pentingnya peranan laboratorium IPA dalam mengembangkan keterampilan dan dalam proses pembelajaran, maka diperlukan sebuah pengelolaan laboratorium yang baik untuk mendukung peran dan fungsi laboratorium. Pengelolaan menurut (Terry dalam Mulyono, 2015) yaitu : Suatu proses yang khas yang terdiri atas tindakan tindakan perencanaan, pengorganisasian, penggerakan atau pelaksanaan, dan pengendalian atau pengawasan yang dilaksanakan untuk menentukan serta mencapai sasaran-sasaran yang telah ditentukan melalui pemanfaatan sumber daya manusia dan sumber-sumber lainnya. Pengelolaan yang baik akan menghasilkan mutu yang baik pula. Dalam bidang pendidikan, yang dimaksud dengan mutu memiliki pengertian sesuai dengan makna yang terkandung dalam siklus pembelajaran. Secara ringkas dapat disebutkan beberapa kata kunci pengertian mutu, yaitu: sesuai standar, sesuai perkembangan kebutuhan, dan sesuai lingkungan global.

Namun penerapan pengelolaan laboratorium IPA di sekolah masih belum sesuai dengan (Peraturan Mentri Pendidikan Nasional, No. 24 Tahun 2007) tentang Standar Sarana Prasarana sekolah khususnya Laboratorium Sekolah/Madrasah. Terlihat berdasarkan hasil analisis data yang dilakukan (Gunawan, 2020) di laboratorium SMPN 3 Sungai Kakap secara keseluruhan aspek yang terdapat di laboratorium belum memenuhi standar untuk melaksanakan kegiatan pembelajaran. Kemudian dari hasil penelitian (Pujani \& Selamet 2020) masih terdapat beberapa masalah karena masih banyak kegiatan pada program perencanaan belum dilaksanakan sesuai dengan apa yang sudah dibuat.

Berdasarkan hasil observasi awal terlihat SMP Negeri 1 Banjar mendapatkan nilai tertinggi ujian nasional pada pelajaran IPA dan peringkat SMP Negeri terbaik di Kota Banjar dengan jumlah peserta 281 memiliki rerata 59,51. Selain itu, sekolah tersebut sudah mendapatkan legalitas dari masyarakat yang ingin menyekolahkan anaknya di sekolah tersebut dikarenakan telah memiliki akreditasi $A$, dan memiliki sarana prasarana yang baik, sekolah tersebut juga memiliki kompetensi lulusan yang telah banyak diterima untuk melanjutkan ke jenjang SMA atau SMK Negeri. Untuk itu peneliti tertarik melakukan penelitian dengan rumusan masalah bagaimana pengelolaan laboratorium IPA dalam meningkatkan mutu pembelajaran IPA di SMP Negeri 1 Banjar. Adapun tujuan penelitian ini untuk mengetahui bagaimana pengelolaan laboratorium IPA dalam meningkatkan mutu pembelajaran IPA di SMP Negeri 1 Banjar.

\section{METODE PENELITIAN}

Lokasi penelitian dilakukan di SMP Negeri 1 Banjar. Metode dalam penelitian ini adalah metode deskriptif kualitatif dengan pendekatan naturalistik. Tujuannya penggunaan metode ini adalah untuk membuat deskripsi secara sistematis, faktual dan akurat tentang fakta-fakta dan sifatsifat obyek tertentu (Wahyu, 2021). Desain penelitian yang digunakan yaitu dengan teknik triangulasi. Dimana teknik triangulasi merupakan gabungan antara teknik observasi, wawancara dengan berbagai sumber yang berkaiatan dengan permasalahan yang diteliti, dan studi dokumentasi yang berkaitan dengan pengelolaan laboratorium dalam peningkatan mutu pembelajaran IPA pada SMP Negeri 1 Banjar. 
Spradly (dalam Sugiono, 2020) dalam penelitian kualitatif tidak menggunakan istilah populasi, tetapi dinamakan social situation atau situasi sosial maka dari itu situasi sosial yang akan diteliti adalah situasi sosial SMP Negeri 1 Banjar yang didalamnya terdapat pelaku yang berkaitan dengan pengelolaan laboratorium IPA serta aktivitas yang ada didalamnya. Dengan Sempel dalam penelitian kualitatif yang dinamakan narasumber (kepala sekolah, pengelola laboratorium IPA, guru IPA, dan siswa). Dalam penelitian ini teknik sampling yang digunakan adalah purposive sampling dan Snowball sampling. Adapun instrument dalam penelitian ini adalah peneliti itu sendiri, dengan menggunakan bantuan pedoman wawancara, pedoman observasi, dan pedoman dokumentasi.

\section{HASIL DAN PEMBAHASAN}

a. Perencanaan Laboratorium IPA

Berdasarkan hasil observasi di SMP Negeri 1 Banjar perencanaan di lakukan dari pengadaan sarana dan prasarana yaitu berasal dari pemerintah, termasuk bangunan laboratorium IPA yang terpisah antara laboratorium fisika dan laboratorium biologi yang memiliki luas masing-masing $96 \mathrm{~m}^{2}$. Namun terdapat kekurangan dalam beberapa hal seperti pada laboratorium fisika, dimana letak dari laboratorium fisika kurang memenuhi syarat sehingga kurangnya ventilasi udara dan pencahayaan di dalam ruangan tentunya hal ini kurang mengacu pada permendiknas No.24 tahun 2007 dimana ruang laboratorium IPA dilengkapi dengan fasilitas untuk pencahayaan yang memadai sehingga dapat digunakan untuk membaca buku dan mengamati obyek percobaan. Selain itu, perlengkapan lain seperti soket dan peralatan PPPK yang masih kurang dimana dalam permendiknas No.24 tahun 2007 dijelaskan pada laboratorium IPA rasio untuk soket listrik berjumlah 9 buah diantaranya dalam meja peserta didik terdapat 1 soket listrik, 2 soket listrik untuk meja demo, dan 2 soket listrik untuk ruang persiapan dan rasio untuk peralatan PPPK 1 buah per laboratorium. Kemudian pada laboratorium biologi kurangnya sumber air atau bak cuci di dalam laboratorium sedangkan dalam permendiknas No.24 tahun 2007 dijelaskan pada laboratorium IPA rasio untuk bak cuci di dalam laboratorium yaitu 1 buah/kelompok dan 1 buah di ruang persiapan, dengan ketersediaan air tentunya akan lebih mempermudah dalam melakukan percobaan.

Perencanaan sarana dan prasarana sekolah harus memenuhi prinsip-prinsip: 1) perencanaan sarana dan prasarana sekolah harus betul-betul merupakan proses intelektual, 2) perencanaan di dasarkan pada analisis kebutuhan, 3) perencanaan sarana dan prasarana sekolah harus realistis, sesuai dengan kenyataan anggaran, 4) visualisasi hasil perencanaan sarana dan prasarana sekolah harus jelas dan rinci, baik jumlah, jenis, merek, dan harganya.

Berdasarkan temuan, secara umum SMP Negeri 1 Banjar sudah melaksanakan prinsipprinsip diatas. Sarana dan prasarana yang direncanakan melainkan bagian dari kepentingan intelektual khususnya dalam pembelajaran praktikum IPA. Selain itu, analisis kebutuhan guru IPA disesuaikan berdasarkan kurikulum yang dilaksanakan. Begitu juga dengan realitas anggaran yang berasal dari BOS baik provinsi maupun pusat. Kemudian hasil perencanaan sarana dan prasarana tersebut divisualisasi dan dirinci kedalam data RKAS.

Program kegiatan, Standar Oprasional Prosedur dan jadwal penggunaan laboratorium IPA di SMP Negeri 1 Banjar sudah tersusun dengan baik dan disesuaikan dengan materi yang akan diajarkan oleh guru IPA. Kepala laboratorium bersama dengan Wakasek Kurikulum dan MGMP IPA di sekolah untuk menentukan jadwal mata pelajaran khususnya yang berkaitan dengan praktikum di laboratorium IPA, hal tersebut bertujuan untuk mengetahui efektifitas dan efisiensi penggunaan sarana dan prasarana. Hal ini sejalan dengan pendapat menurut Kauffman (dalam Fattah, 2013) bahwa perencanaan adalah proses penemuan tujuan atau sasaran yang hendak dicapai dan menetapkan jalan dan sumber daya yang diperlukan untuk mencapai tujuan itu seefesien dan seefektif mungkin. 
Dengan perencanaan program tersebut diharapkan tujuan pembelajaran IPA akan tercapai sehingga dapat menghasilkan mutu pembelajaran IPA yang diinginkan. Hal ini sejalan dengan mutu dalam MPMBS yaitu memiliki makna mutu proses dan mutu hasil. "Proses Pendidikan" yang bermutu melibatkan sebagai input, seperti: bahan ajar, metodologi, sarana sekolah, dukungan administrasi, dan sarana prasarana dan sumber daya lainnya serta penciptaan suasana yang kondusif. Mutu "Hasil Pendidikan" mengacu pada prestasi yang dicapai oleh sekolah pada setiap kurun waktu tertentu. Prestasi yang dicapai atau hasil pendidikan dapat berupa prestasi akademik maupun non-akademik (Koswara \& Triatna, 2014).

b. Pengorganisasian Laboratorium IPA

Pihak SMP Negeri 1 Banjar dalam menentukan perangkat pengelolan laboratorium IPA yang dinilai mampu menggerakan dan memberi pelayanan laboratorium IPA terhadap pihak pengguna, untuk pengelola laboratorium IPA di sekolah ini guru merangkap menjadi pengelola laboratorium dikarenakan tidak adanya tenaga pengelola khusus. Adapun struktur organisasi laboratorium SMP Negeri 1 Banjar sebagai berikut:

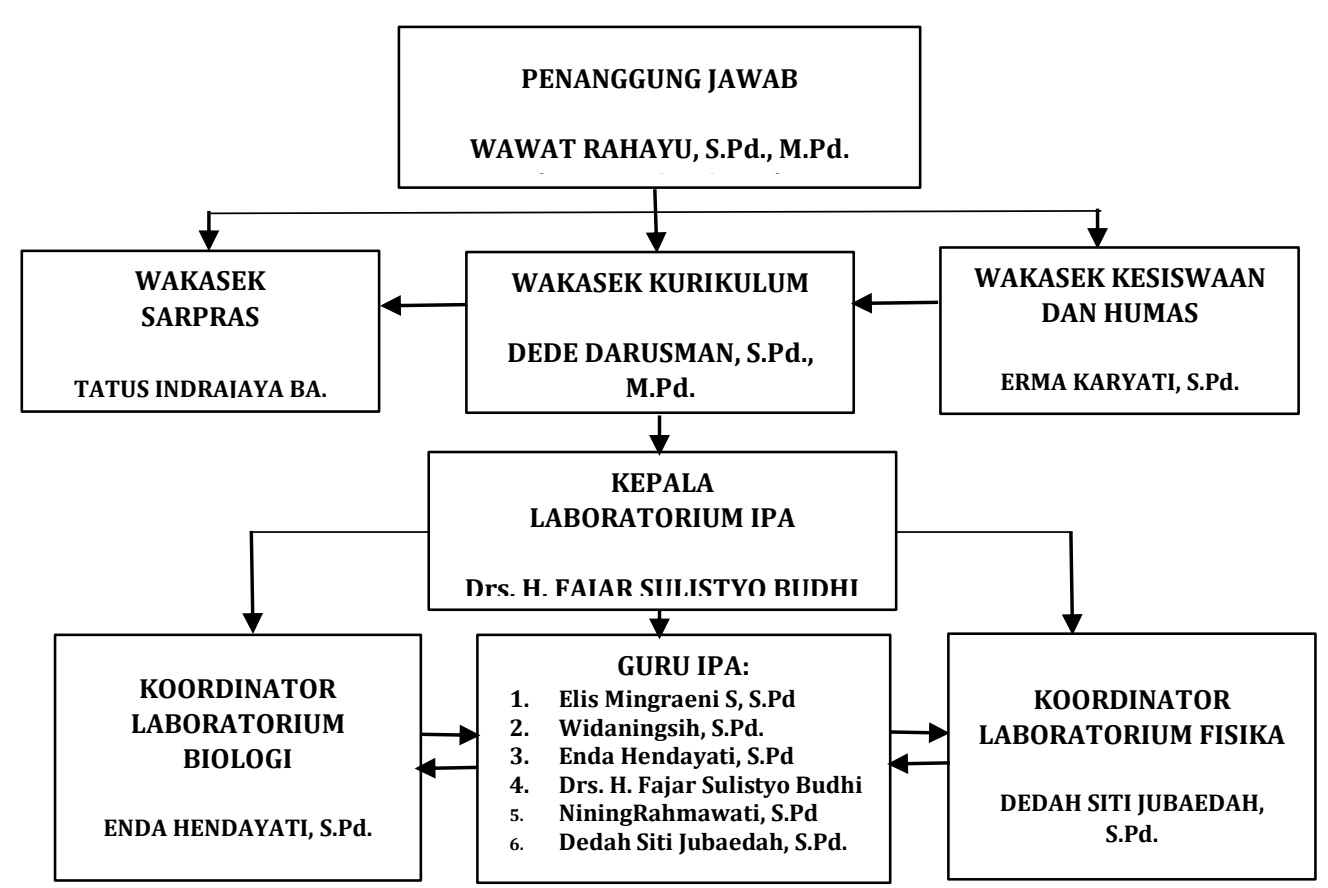

Gambar 1. Struktur Pengelola laboratorium SMP Negeri 1 Banjar

Menurut Terry dalam bukunya Principles of Management mengemukakan pengorganisasian ialah penentuan, pengelompokkan, dan penyusunan macam-macam kegiatan yang diperlukan untuk mencapai tujuan, penempatan orang-orang (pegawai), terhadap kegiatan-kegiatan ini, penyediaan faktor-faktor physik yang cocok bagi keperluan kerja dan penunjukkan hubungan wewenang, yang dilimpahkan terhadap setiap orang dalam hubungannya dengan pelaksanaan setiap kegiatan yang diharapkan. Dalam hal ini pengorganisasian pada pengelolaan laboratorium IPA di SMP Negeri 1 Banjar secara umum cukup baik. Sekolah tersebut memiliki pengelola laboratorium yang cukup kompeten. Namun hal ini belum bisa dikatakan lengkap dikarenakan dalam Permendiknas No. 26 tahun 2008 pasal 1 ayat 1 sudah dijelaskan bahwa hendaknya standar tenaga laboratorium sekolah/madrasah mencakup kepala laboratorium sekolah/madrasah, teknisi laboratorium sekolah/madrasah, dan laboran sekolah/madrasah. 
Secara struktural, laboratorium IPA di SMP Negeri 1 Banjar belum memiliki tenaga khusus laboran dan teknisi. Namun dalam praktiknya peraran tersebut digantikan oleh tenaga pengelola lain baik kepala laboratorium IPA, koordinator laboratorium fisika, koordinator laboratorium biologi, guru IPA, dan terkadang melibatkan siswa yang saling bekerjasama khususnya dalam tahap persiapan dan pemeliharaan laboratorium dan tanpa mengesampingkan tugas utama mereka.

c. Pelaksanaan Laboratorium IPA

Di SMP Negeri 1 Banjar, secara umum pelaksanaan sudah cukup baik terlihat dari kesesuaian kegiatan dan layanan dengan program yang telah direncanakan. Namun, terdapat kendala sumber daya manusia (SDM) dan ketersediaan sarana prasarana laboratorium IPA. Akan tetapi kendala tersebut masih bisa diatasi dengan guru IPA yang harus lebih kreatif dalam mengatasi hal tersebut sehingga kegiatan praktikum tetap dilaksanakan. Selain itu, dilihat berdasarkan rombel di SMP Negeri 1 Banjar dan ketersediaan laboratorium, untuk pembelajaran praktikum di laboratorium kemungkinan besar tidak dapat dilakukan setiap hari maka pelaksanaan kegiatan praktikum disesuaikan dengan bobot materi yang diajarkan. Tak hanya itu, tidak semua materi juga dapat dilakukan praktikum. Pelaksanaan adalah usaha semua anggota kelompok dengan sedemikian rupa supaya berkeinginan dan berusaha dengan keras untuk mencapai tujuan yang serasi dengan perencanaan dan usaha-usaha pengorganisasian dari pihak pimpinan.

Berbeda dengan saat ini pelaksanaan pengelolaan laboratorium IPA kurang optimal dikarenakan adanya pandemi virus Covid-19, yang mengharuskan kegiatan pendidikan serta proses kegiatan belajar mengajar dialihkan menjadi pembelajaran jarak jauh yaitu menggunakan jaringan/virtual. Begitu juga proses pengelolaan laboratorium seperti kegiatan praktikum yang harus tetap berjalan meskipun dengan adaptasi dan pendekatan yang berbeda dengan menggunakan praktikum berbasis virtual. Akan tetapi hal ini tidak menghalangi pengelola laboratorium besreta guru untuk melakukan kegiatan pembelajaran IPA dan pelayanan. Dalam pelaksanaan pembelajaran tetap dilakukan menggunakan video atau berbagai media interaktif agar siswa dapat lebih mudah dalam memahami materi yang dia ajarkan. Hal ini sejalan dengan pendapat Sutarti \& Irawan, (2017) bahwa media interaktif dapat berupa software dan hardware yang dapat digunakan sebagai perantara untuk menyampaikan materi pelajaran kepada siswa yang dapat memungkinkan siswa berinteraksi dengan lingkungan pembelajaran.

d. Pengawasan Laboratorium IPA

Supervisi atau pengawasan laboratorium IPA di SMP Negeri 1 Banjar dilihat dari laporan kepala laboratorium kepada kepala sekolah baik secara formal maupun informal. Laporan kepala laboratorium tersebut dilakukan dua kali dalam satu tahun. Untuk semester pertama subtansi yang di supervise yaitu menegnai adminitrasi, dimana pengecekan kelengkapan administrasi dari perencanaan, dan pengorganisasian. Kemudian untuk semester ke dua substansi yang disupervisi adalah supervisi yang bertujuan untuk melihat bagaimana kegiatan dilaboratorium apakah berjalan dengan baik atau tidak. Tak hanya itu Setiap kegiatan pengelolaan laboratorium IPA juga disupervisi termasuk kinerja pengelola dan guru IPA dalam kegiatan praktikum. Disamping itu, kondisi dan peralatan yang diperlukan juga dilaporkan kepada kepala sekolah sebagai acuan untuk pengadaan ditahun depan. Pengawasan dapat dirumuskan sebagai proses penentuan apa yang harus dicapai yaitu standard, apa yang sedang dilakukan yaitu pelaksanaan, menilai pelaksanaan, dan bilamana perlu melakukan perbaikan-perbaikan, sehingga pelaksanaan sesuai dengan rencana, yaitu selaras dengan standard (ukuran). 


\section{KESIMPULAN}

Pengelolaan laboratorium IPA SMP Negeri 1 Banjar di mulai dari :

a. perencanaan pengadaan sarana prasarana masih terdapat kekuranan terlihat dari letak laboratorium fisika yang kurang memenuhi syarat sehingga kurangnya ventilasi udara dan pencahayaan di dalam ruangan, dan pada laboratorium biologi masih kurangnya sumber air atau bak cuci. Akan tetapi dalam penyusunan program kegiatan, maupun alat dan bahan yang dapat menunjang kegiatan pembelajaran di laboratorium IPA sudah dipersiapkan dengan baik.

b. Pengorganisasian terlaksana dengan cukup baik, pengorganisasian yang dilakukan adalah dengan memanfaatkan kemampuan guru IPA yang berkompeten dan dianggap mampu untuk mengelola laboratorium IPA. Akan tetapi masih terdapat kekurangan pada tenaga pengelola yaitu laboran dan teknisi khusus.

c. Pelaksanaan, dari perencanaan yang telah disusun secara umum sudah terlaksana sesuai dengan perencanaan dan jadwal penggunaan laboratorium IPA juga disesuaikan dengan kebutuhan dari masing- masing guru IPA. Namun berbeda pada masa pandemi covid-19 ini dalam pelaksanaan kegiatan laboratorium kurang optimal dikarenakan kegiatan pendidikan atau pembelajaran dilakukan secara virtual/daring.

d. Pengawasan secara umum sudah dilaksanakan melalui supervisi, mentoring dan evaluasi yang dilakukan dua kali dalam setahun oleh pihak-pihak yang bertujuan sebagai bahan perbaikan dan pengembangan dalam pengelolaan laboratorium IPA sehingga dapat meningkatkan mutu pembelajaran IPA.

\section{REKOMENDASI}

Rekomendasi yang dikemukakan dalam pengelolaan laboratorium IPA dalam meningkatkan mutu pembelajaran IPA yaitu memperhatikan pengelolaan laboratorium IPA agar tetap maksimal termasuk kelengkapan struktur organisasi seperti laboran dan teknisi agar dapat membantu dalam pelaksanaan kegiatan praktikum.

\section{UCAPAN TERIMAKASIH}

Penulis mendapatkan banyak dukungan dari berbagai pihak, dengan segala kerendahan hati penulis mengucapkan terima kasih yang sebesar-besarnya kepada Ibu Wawat Rahayu, S.Pd., M.Pd., selaku kepala sekolah SMP Negeri 1 Banjar dan jajarannya yang telah membantu dalam memberikan data.

\section{DAFTAR PUSTAKA}

Fattah, N. (2013). Landasan Manajemen Pendidikan. 2nd ed. Bandung: PT. Remaja Rosdakarya.

Gunawan, M. (2020). "Analisis Manajemen Laboratorium IPA Di SMPN 03 Sungai Kakap Kabupaten Kubu Raya."

Koswara, D., \& Triatna, C. (2014). Manajemen Pendidikan. 7th ed. ed. Riduan. Bandung: Alfabeta, CV.

Mulyono, N. (2015). Pengelolaan Pendidikan. Bandung: Rizqi Press.

Peraturan Mentri Pendidikan Nasional. (2007). Peraturan Menteri Pendidikan Nasional Republik Indonesia Nomor 24 Tahun 2007 Tentang Standar Sarana Dan Prasarana. Jakarta.

Pujani, Ni Made, and Kompyang Selamet. (2020). "Pengelolaan Laboratorium IImu Pengetahuan Alam ( IPA ) SMP Negeri 2 Singaraja." 3(3): 118-29. 
Sugiyono. 2020. Metode Penelitian Kuantitatif Kualitatif Dan R\&D. 28th ed. Bandung: Alfabeta, cv.

Syafri, Edi; Endrizal, NFN. (2013). "Pembelajaran Berbasis Praktikum Sebagai Sarana Siswa Untuk Berlatih Menerapkan Keterampilan Proses Sains Dalam Materi Biologi." Journal of Chemical Information and Modeling 53(9): 1689-99.

Wahyu F. S. (2021). Pemanfaatan instagram sebagai media alternatif ipa dalam masa pembelajaran jarak jauh (pjj). J-KIP (Jurnal Keguruan dan IImu Pendidikan), 2 (2), 81-90. 
